\title{
Effect of Sixteen Weeks of Fartlek Training on Self- Esteem of Saudi University Students
}

\author{
Varghese C Antony* and Rakesh Tomar \\ Physical Education Department, King Fahd University of Petroleum and Minerals, Dhahran-31261, Saudi Arabia; \\ vcantony@kfupm.edu.sa
}

\begin{abstract}
Objectives: Self-esteem is considered one of the fundamental indicators of mental health (Fox, 2000). The objective was to examine the effect of 16 weeks of supervised fartlek training on self-esteem on undergraduate students $(n=40$; Mage 18.52 years). Methods/Statistical Analysis: Two groups were formed and randomized into intervention $(\mathrm{n}=20)$ which was given 16 weeks of supervised fartlek training program and control group $(n=20)$. Control group participants continued with daily routine. Time duration of the training program was 45 minutes per session, twice per week. Rosenberg's Self-esteem scale (1965) was administered to both groups prior and after 16 weeks of intervention program. Wilcoxon signed rank test and Mann-Whitney Test was used to determine the differences between pre and post scores and between groups respectively. Findings: Significant difference was notified between pre and post fartlek intervention group on self-esteem 22 (5) versus 25 (4), p<.001. No significant difference observed on self-esteem between pre and post median score of students' in the control group where physical activity $<4$ hours per week 23 (4) and 24 (2), $\mathrm{P}=.475$; but it showed significantly different where the physical activity $\geq 4$ per week 23.5 (5) and 26 (4), P= .045. Application/Improvement: Self-esteem improved with sixteen weeks of fartlek intervention program. It was suggested that students who were not adequately engaged in physical activities that is $<4$ hours per week need to undergo an intervention program or be motivated to engage in regular physical activities 4 hours and more per week in order to boost their self-esteem.
\end{abstract}

Keywords: Fartlek Training, Physical Activity, Self-esteem, University Student

\section{Introduction}

One of the essential desires of human being is a feeling of self-worth or self-esteem that may disturb their growth, development, and identity. It is believed that self-esteem has two aspects called internal and external aspects. Internal aspect comprises of self-love, self-recognition, having clear goals, positive thinking; whereas external aspect involves communication with others, self-opinion, appearance in the community, and control of emotions. This aspect also facilitates people to behave in such a way as to appear self-confident in sight of the outside world, and internal aspect presents people a sense of being good ${ }^{1}$. It is believed that self-esteem has been a key element of mental health ${ }^{2}$.

Self-esteem defined as the positivity of the person's evaluation of the self ${ }^{3}$. Self-esteem is the personal judg- ment of worthiness that is expressed in the attitude the person holds towards himself $\mathrm{f}^{4}$. There is a universal harmony that high self-esteem is always linked with better psychological wellbeing and low self-esteem is allied with the lower psychological health and functioning Self-esteem is how a person evaluates himself positively or negatively ${ }^{6}$. Scientists confirmed the significance of self-esteem as subjective quality of life, behavioral competence, positive self-experience, and self-actualization ${ }^{?}$.

Perceptual, conceptual and attitudinal are three components of self-esteem. Perceptual means what the individual perceives as his /her body image and worth along with what others' perceive of him/her. The individual's concept of abilities, limitations and characteristics of self represents conceptual component. This component depends on the thought process, perception and cognitive understanding of oneself ${ }^{8}$. Attitudinal component

${ }^{*}$ Author for correspondence 
originates from the person's feeling for himself which include aspiration conviction, ideals, values and beliefs. Perceiving these components positively will make person experience a positive self-worth, but if considered negatively then the individual possesses a poor self-worth ${ }^{9,10}$.

High self-esteem individuals were often characterized with superior mental health, high self-confidence, better social behavior and low level of stress whereas, low selfesteem individuals were low in confidence, sad, always complained about social problems, and had higher perceived stress ${ }^{\underline{11}}$. Persons feeling about themselves influence their interaction with surroundings $s^{12}$.

Research studies in the field of physical activities and sports participation have established that physically active people are physically strong and psychologically sound ${ }^{13}$. Factors that influence self-esteem positively are participation in sports and physical activities, appearance, academic achievements, family, contentment, right behavior and social respect ${ }^{14}$. People who take part in competitive and recreational sports activities were observed to improve in their physical appearance and become more socially compatible with others. Further, it developed a positive attitude towards physical activities in them ${ }^{15}$. University students enhanced their self-esteem and self-efficacy through strength note program ${ }^{16}$. The feedback and appreciation from their peers always encourages their participation in physical activities which in turn improved their self-esteem ${ }^{17}$. Sports participation promotes higher self-esteem which enables individuals to become well-adjusted to society as it develops new skills, values and team spirit $\frac{18}{}$. Global self-esteem increased by sports participation which also improved physical appearance and emotional self-esteem $\frac{19}{}$.

Self-esteem has become a household word for teachers and parents; the notion that high self-esteem will result in many positive outcomes and benefits. Thus, present study examined effects of sixteen weeks of supervised fartlek training and self-esteem on undergraduate students.

\section{Methods}

\subsection{Participants}

Forty undergraduate students enrolled in the various courses at King Fahd University of Petroleum and Minerals (KFUPM), were selected randomly. A criterion for enrolment was participants who were involved in regular physical activity at least for the last 6 months. The participants who were obese $\left(\mathrm{BMI} \geq 30 \mathrm{~kg} /{ }^{\mathrm{m} 2}\right)$, with cardiovascular diseases, with serious illness and on prescribed medication were excluded.

\subsection{Measure}

Self-Esteem questionnaire developed in ${ }^{20}$ was employed to evaluate self-esteem. Questionnaire had ten items that measure global self-worth by determining both positive and negative feelings about 'self'. This scale is assumed to be unidimensional. All items were responded on a 4-point Likert scale- from strongly agree to strongly disagree. The RSES score is calculated on five positively worded items 1,2,4,6 and 7; the response format score was ( 0 = strongly disagree, 1 = disagree, $2=$ agree, $3=$ strongly agree) and for negatively worded items 3,5,8,9 and 10 the scores were reversed for computation. The range for total obtained scores was from 0-30. High score means greater self-esteem. The questionnaire was highly reliable with test-retest correlations ranged from .82 to .88 .

\subsection{Intervention}

Supervised whistle-fartlek training program of Mackenzie ${ }^{21}$ was carried out for 16 weeks on a synthetic running track. Duration of the training program was 45 minutes twice a week. Fartlek training included 10 minutes warm up, followed by pyramid sessions of 4-3-2-1-2-3-4 minutes with a 60 second jog-walk recovery between each run. Each training session ended with 10 minutes cool down exercises. When the whistle was blown, the athletes ran hard until the next whistle was blown again. Daily attendance was recorded.

\subsection{Procedure}

Two groups were formed, randomized into intervention $(n=20)$ that were given 16 weeks of supervised fartlek training program while the control group $(n=20)$ were asked to follow their regular tasks without part taking in any other physical activities / exercise program. The duration of the training program was 45 minutes per session, twice a week. Both groups were administered Rosenberg Self-esteem Scale ${ }^{20}$ prior and after sixteen weeks of the intervention program. All participants signed a consent form before participation. Participation enrolled in the study voluntarily. The survey was administered in the classroom setting before and after sixteen weeks 
of fartlek program. The subjects were informed that the data collected will be kept strictly confidential. Prior to the research study, formal approval was sought from the university research committee for financial aid from DSR, KFUPM.

\subsection{Analysis}

Due to small sample population, non-parametric statistics was used to study the effect. Mann Whitney Test was used to determine the differences among two groups after 16 weeks of fartlek training program. Mann Whitney U-test for non-parametric comparisons was also applied to check if any significant differences existed between groups. Level of significance was set for $\mathrm{p}$ values $<0.05$.

\section{Results}

Table 1. Self-esteem of university students before and after 16 weeks of Fartlek training program

\begin{tabular}{|l|l|l|l|}
\hline \multirow{2}{*}{ Groups } & Pre test & Post test & Significance \\
\cline { 2 - 3 } & $\begin{array}{l}\text { Median } \\
(\mathrm{IQR})\end{array}$ & $\begin{array}{l}\text { Median } \\
(\mathrm{IQR})\end{array}$ & \\
\hline Intervention & $22(5)$ & $25(4)$ & $<0.001^{\star \mathrm{a}}$ \\
\hline Control & $23(4)$ & $24(3)$ & $0.58^{\mathrm{a}}$ \\
\hline Significance & $0.92^{\mathrm{b}}$ & $0.03^{\star \mathrm{b}}$ & \\
\hline
\end{tabular}

a-Wilcoxon signed rank test and b-Wilcoxon Mann Whitney U test

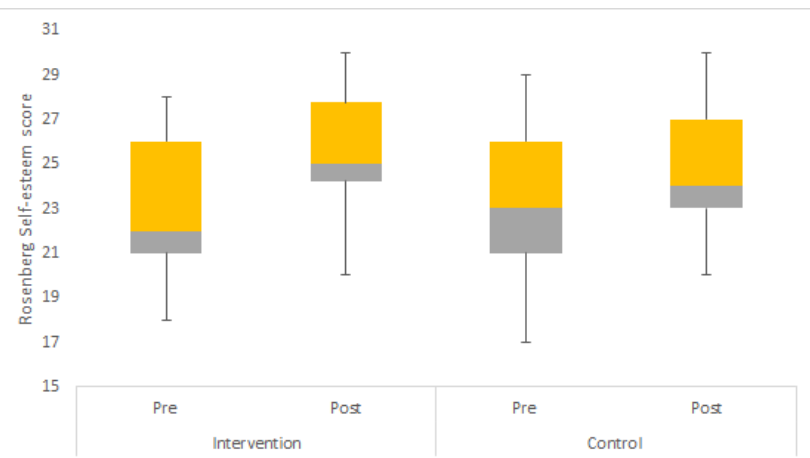

Figure 1. Self-esteem of university students before and after 16 weeks of Fartlek training program

Table 1 revealed that intervention group had improved self-esteem significantly after sixteen weeks of supervised fartlek training program as the Wilcoxon signed rank test scores exhibited highly significant difference between intervention median values on self-esteem 22 (5) and 25 (4), $p=.001$. No significant difference seen among the control group's pre and post- tests score 23 (4) and 24 (3), $\mathrm{p}=0.058$. Mann Whitney U-test carried out to explore any significant difference among intervention and control groups. The pre-test scores of intervention and control groups on self-esteem showed no significant difference as the scores were 22(5) versus 23(4), $\mathrm{p}=0.92$. Participants of intervention group after 16 weeks of fartlek training program exhibited statistically significant increase on their self-esteem as the score shows 25 (4) and 24 (3), p=0.03 as shown in Figure 1.

Table 2. Self-esteem of university students whose amount of physical activity is $\geq 4$ hours Physical activity $\geq 4$ hours per week

\begin{tabular}{|l|l|l|l|}
\hline Groups & Pre & Post & Significance \\
\cline { 2 - 3 } & $\begin{array}{l}\text { Median } \\
(\mathrm{IQR})\end{array}$ & $\begin{array}{l}\text { Median } \\
(\mathrm{IQR})\end{array}$ & \\
\hline Intervention & $24(4)$ & $27.5(4)$ & $0.026^{\star}$ \\
\hline Control & $23.5(5)$ & $26(4)$ & $0.045^{\star}$ \\
\hline
\end{tabular}

${ }^{\star}$ Wilcoxon signed rank test

Table 2 showed a significant Wilcoxon signed rank test result among both groups who were engaged in physical activities $\geq 4$ hours per week. The intervention group obtained 24(4) versus 27.5(4), $\mathrm{p}=0.026$ and the control group exhibited 23.5(5) versus 26(4), $\mathrm{p}=0.045$ which were also significant at 0.05 level.

\section{Discussion}

Self-esteem is considered an important indicator of psychological health and social life adjustment. Self-esteem is also considered to have strong connections to our wellbeing along with life quality. Participation in games and sport and healthy behavior is associated often with high self-esteem, while mental illness and absence of wellbeing is related low self-esteem $\frac{22,23}{}$. It is also noticed that psychologically healthy and happy individual have high self-esteem ${ }^{24,2}$ whereas, psychologically depressed and distressed people have low self-esteem ${ }^{25}$.

The results revealed that 16 weeks of intervention fartlek-training program improved the self-esteem of undergraduate university students. This result was supported by the findings of that self-esteem was enhanced with aerobic exercise program. They also established a strong correlation between physical exercise and psy- 
chological health component such as self-esteem ${ }^{26}$. Established that regular exercise program is an influencing factor for betterment of self-esteem in female university students in Turkey ${ }^{27}$.

Further the results indicated that students who were physically active for 4 or more hours per week showed better self-esteem. Thus it was inferred that students who were physically inactive less than 4 hours per week, only needed the intervention program.

Participation in exercise program significantly improved the self-esteem was confirmed by ${ }^{28}$. Shin and Kim reported that cyclists, cycling longer period per week enhanced their self-esteem ${ }^{29}$. Physical exercise is a major contributor to good health. Recreational exercise activity can improve physical health and also contribute significantly to well-being psychologically and betterment of self-esteem and confiedence ${ }^{30,23}$.

\section{Conclusion}

Study concluded that the effect of 16 weeks of supervised intervention fartlek training program improved selfesteem in university undergraduate students. It was also noticed, students who were adequately engaged in physical exercises sports activities for nearly more than four hours a week showed better self-esteem. It was suggested that students who were physically inactive that is $<4$ hours per week need to undergo an intervention program or be motivated to involve in regular physical exercises to boost their self-esteem.

\section{Acknowledgement}

The authors would like to acknowledge the support provided by the Deanship of Scientific Research at King Fahd University of Petroleum \& Minerals (KFUPM) under Research Grant IN141041.

\section{References}

1. Huang JS, Norman GJ, Zabinski MF, Calfas K, Patrick K. Body image and self-esteem among adolescents undergoing an intervention targeting dietary and physical activity behaviors. Journal of Adolescent Health. 2007; 40(3):24551.

2. Taylor SE, Brown JD. Illusion and well-being: a social psychological perspective on mental health. Psychological Bulletin. 1988; 103(2):193.
3. Bandura A. Self-efficacy: The exercise of control. New York. 1997.

4. Kohn A. The truth about self-esteem. Phi Delta Kappan. 1994; 76(1): 272.

5. Glaus K. Measuring self-esteem. In: Enhancing self-esteem. Philadelphia. 1999; 3(1):457-75.

6. Baumeister B , Roy F. Self-esteem. In: Encyclopedia of human behavior. New York: Academic Press;1994; 4:83-7.

7. Ng JY, Tam SF, Man DW, Cheng LC, Chiu SW. Gender difference in self-esteem of Hong Kong Chinese with cardiac diseases. International Journal of Rehabilitation Research. 2003; 26(1): 67-70.

8. Battle J, Blowers T. A longitudinal comparative study of the self-esteem of students in regular and special education classes. Journal of Learning Disabilities. 1982;15(2):100-2.

9. Hall AL. The relationship between academic achievement, academic performance and self-esteem of high school juniors at a public high school in central Florida. ProQuest: Ann Arbor, 2007.

10. Yigiter K. Investigation of the problem solving-skill, selfesteem and preferences of the university students regarding sport and social activity in Turkey. International Journal of Academic Research. 2013 July;5(4): 220_26.

11. Gerber M, Pühse U. Don’t crack under pressure! , Do leisure time physical activity and self-esteem moderate the relationship between school-based stress and psychosomatic complaints? Journal of Psychosomatic Research. 2008;65(4):363-9.

12. Kernis MH. Toward a conceptualization of optimal selfesteem. Psychological Inquiry. 2003; 14(1):1-26.

13. Barnett NP, Smoll FL, Smith RE. Effects of enhancing coach-athlete relationships on youth sport attrition. Sport Psychologist. 1992 June; 6(2):111-27.

14. Gentile B, Grabe S, Dolan-Pascoe B, Twenge JM, Wells BE, Maitino A. Gender differences in domain-specific selfesteem: A meta-analysis. Review of General Psychology. 2009 March;13(1):34-45.

15. Waldron JJ. Development of life skills and involvement in the Girls on Track program. Women in Sport and Physical Activity Journal. 2009 October;18(2):60-73.

16. Lee YJ, Park SJ. The effects of strength note program on the self-esteem and self-efficacy of university students: a longitudinal study. Indian Journal of Science and Technology. 2015 Oct; 8(26):1-5.

17. Kirkcaldy BD, Shephard RJ, Siefen RG. The relationship between physical activity and self-image and problem behavior among adolescents. Social Psychiatry and Psychiatric Epidemiology. 2002; 37(11):544-50.

18. Sanford N, Borgstrom K, Lozoff M. The role of athletics in student development. New Directions for Higher Education. 1973; (3):51-68. 
19. Jackson SA, Marsh HW. Athletic or antisocial? The female sport experience. Journal of Sport Psychology. 1986; 8(3):198-211.

20. Rosenberg M. Society and the adolescent self-image. Princeton University Press: New Jersey, 1965.

21. Fartlek Training. Dated accessed: 04/08/2013. Available from: http://www.brianmac.co.uk/fartlek.htm

22. Fox KR. Advances in the measurement of the physical self. Advances in Sport and Exercise Psychology Measurement. 1998;1(1):295-310.

23. Fox KR. The effects of exercise on self-perceptions and selfesteem. Physical Activity and Psychological Well-Being. 2000; 13(5):81-118.

24. Branden N. The six pillars of self-esteem. Bantam Books: New York, 1994.

25. Tennen H, Affleck G. The Puzzles of Self-Esteem a Clinical Perspective. In: Self-Esteem. Springer.: US. 1993; p.241-46
26. Salamuddin N, Harun MT, Al-Rashed SA. The effects of selected aerobic exercise modalities on self-esteem among female students. Asian Social Science. 2014 March;10(5):141-45.

27. Yìgiter $\mathrm{K}$. The effects of participation in regular exercise on self-esteem and hopelessness of female university students. Social Behavior and Personality: An International Journal. 2014; 42(8):1233-43.

28. Spence JC, McGannon KR, Poon P. Exercise Psychology. Journal of Sport \& Exercise Psychology. 2005;27: 311-34.

29. Shin E, Kim H. Factors influencing health-related quality of life among male workers in Korea. Indian Journal of Science and Technology. 2015 Jan; 1(8):236-46.

30. Stambulova N, Johnson U, Lindwall M, Hinic H. Grant Proposal: Athletes' perceived health: a benefit or a cost of a multiyear sport participation. School of Social and Health Sciences. Halmstad University, 2004; p. 1-40. 